\title{
Stability and Adaptability of Yield among Earliness Sweet Corn Hybrids in West Java, Indonesia
}

\author{
Dedi Ruswandi $\mathbb{D}^{1},{ }^{1}$ Yuyun Yuwariah, ${ }^{1}$ Mira Ariyanti, ${ }^{1}$ Muh Syafii, ${ }^{2}$ and Anne Nuraini ${ }^{1}$ \\ ${ }^{1}$ University of Padjadjaran (Unpad), Faculty of Agriculture, Jl. Raya Bandung-Ujungberung km.21, 45363 Sumedang, Indonesia \\ ${ }^{2}$ Universitas Singaperbangsa Karawang (Unsika), Faculty of Agriculture, Jawa Barat, Indonesia \\ Correspondence should be addressed to Dedi Ruswandi; d.ruswandi@unpad.ac.id
}

Received 11 March 2020; Revised 26 June 2020; Accepted 7 July 2020; Published 30 July 2020

Academic Editor: David Clay

Copyright $\odot 2020$ Dedi Ruswandi et al. This is an open access article distributed under the Creative Commons Attribution License, which permits unrestricted use, distribution, and reproduction in any medium, provided the original work is properly cited.

Multienvironment testing is an important phase to study the interaction of $\mathrm{G} \times \mathrm{E}$ and to select stable hybrids for a broad environment or for a specific environment. To study the interaction of $\mathrm{G} \times \mathrm{E}$ and the stability of earliness and yield of Indonesian new sweet corn hybrids under different locations and seasons in West Java, Indonesia, eighteen hybrids were evaluated in six environments in West Java, Indonesia, and were analysed using parametric and nonparametric stability models, additive main effects and multiplicative interaction (AMMI), and GGE biplots. Results showed that the most promising sweet corn hybrids including hybrids G5 (SR 24 x SR 17) and G11 (SR 31 x SR 17) were identified. The parametric and nonparametric stability parameters and ASV were complement to the AMMI and GGE biplots in selecting stable and adaptable hybrids in terms of earliness and yield. G5 was selected as a high-response hybrid for grain yield to Jatinangor (E1, E2), Lembang (E3, E4), and Wanayasa (E5, E6), as well as earliness to Jatinangor (E2), Lembang (E3, E4), and Wanayasa (E5, E6). G5 sweet corn hybrid, therefore, is suggested to be extensively evaluated on farm and produced for smallholder farmers in West Java, Indonesia.

\section{Introduction}

Sweet corn is a major and an important vegetable cultivated in Indonesia. This vegetable contains complete nutrients, such as carbohydrates, protein, vitamins, and several important minerals. The demand for sweet corn in Indonesia is increasing dramatically nowadays, but production and its productivity are low due to some limiting factors including variations in agroclimate conditions and cultivation of nonhybrid sweet corn [1].

Production and productivity of sweet corn in Indonesia can be increased by cultivating early-maturing hybrids, improving productivity of the land, and rotating early-maturing hybrids which are adaptive to particular agroclimate and planting times. This strategy could be successfully implemented if earlymaturing and high-yield hybrids can be selected.

Earliness and high yield are important characteristics of sweet corn varieties to develop in West Java, Indonesia. Farmers usually cultivate sweet corn in unirrigated rice field at the end of rainy season or at the very early part of the rainy season when water is available for irrigating sweet corn but not enough for irrigating the rice paddy field. Earliness and high yield are complex traits, which are inherited by polygenic inheritance [2]. Selection of the superior hybrid with early maturing ability and high yield, therefore, is only possible to perform when information about the interaction of genotype $\times$ environment is available.

Multienvironment test (MET) is a critical stage in hybrid selection before superior hybrids are commercially released. MET is conducted to analyze the interaction of hybrid $\times$ environment $(\mathrm{G} \times \mathrm{E})$ and to select stable hybrids for a broad environment or to select adaptive hybrids for a specific environment [3]. Crop evaluation under different agroclimatic conditions and year during MET influences the phenotypic stability of particular genotypes [4]. Selection of the genotype with high yield under different environments was difficult due to complex responses of the crop as indicated by inconsistency of its rank in different locations. Therefore, identification of causal factors of the IGE is important to decide the breeding objectives, ideal location of MET, and selection of regional-adaptive genotypes. 
Some statistical methods are commonly applied to define stability and adaptability of new varieties, i.e., ANOVA, linear/nonlinear regression, multivariate analysis, nonparametric method, and biplot. AMMI (additive main effects and multiplicative interaction model) analysis and GGE biplot are multivariate statistic methods to study the interaction of $\mathrm{G} \times \mathrm{E}$, stability, and adaptability based on the biplot. AMMI is applied to analyze stability as well as IGE in many important crops such as barley $[5,6]$, Mesoamerican bean [7], faba bean $[8,9]$, maize [10-13], passion fruit [14], rice [15], potatoes [16], sugarcane [4], sun flowers [17], sweet sorghum [18], and wheat [19].

Yan et al. [20] recommended the GGE (genotype and genotype-environment interaction) biplot as a modification of AMMI to select and to identify potential high-yield varieties which are stable and adaptive under multienvironment conditions. GGE biplot had been used to analyze the interaction of $\mathrm{G} \times \mathrm{E}$ by many breeders in many crops such as barley [5], chickpeas [21], maize [3, 13, 20], sorghum $[18,22]$, Mesoamerican bean [7], and wheat [23].

The objective of the research is to study the interaction of $\mathrm{G} \times \mathrm{E}$, stability, and adaptability of earliness and yield of sweet corn hybrids under different locations and seasons in West Java, Indonesia.

\section{Materials and Methods}

2.1. Experimental Materials and Treatments. The experiment was run in three locations in West Java, namely, JatinangorSumedang (760 m above sea level-asl.), Lembang-Kabupaten Bandung Barat (950 m asl.), and Wanayasa-Kabupaten Purwakarta (700 $\mathrm{m}$ asl.), for two different seasons, i.e., season 1 (March-July, 2017) and season 2 (March-July,
2018). Sixteen new Indonesian sweet corn hybrids and two check hybrid cultivars, namely, BS (G1), SB (G2), SR 15 x 17 (G3), SR $22 \times 17$ (G4), SR 24 x SR 17 (G5), SR 25 x SR 17 (G6), SR 26 x SR 17 (G7), SR 30 x SR 17 (G8), SR 31 x SR 17 (G9), SR 32 x SR 17 (G10), SR 33 x SR 17 (G11), SR 4 x SR 17 (G12), SR $41 \times$ SR 17 (G13), SR 43 x SR 17 (G14), SR 46 x SR 17 (G15), SR $47 \times$ SR 17 (G16), SR $52 \times$ SR 17 (G17), and SR 9 $x$ SR 17 (G18), were evaluated. The genetic materials were planted in a randomized complete block design with three replications in each location and each season.

2.2. Statistical Analysis. Analysis of variance (ANOVA) for earliness (male flowering) and yield followed the study of Gomez and Gomez [24]. Homogeneity of variance error for six locations and two seasons was tested using Bartlett test [24]. Combined ANOVA for the six locations and two seasons was pursued to determine the interaction of $\mathrm{G} \times \mathrm{E}$ when variance errors were homogenous.

Stability and adaptability of hybrids were determined using parametric and nonparametric stability as well as multivariate analysis. Parametric stability to be estimated included linear regression coefficient (bi) and AMMI stability value (ASV), whereas nonparametric stability included $\mathrm{S}_{\mathrm{i}}[25,26]$, NP [27], and $\mathrm{Kr}$ [28]. Multivariate analysis was done using AMMI and GGE biplot as well.

Linear regression was estimated using Eberhart and Russell's study [29]. Based on this model, if the regression coefficient $\left(b_{i}\right)$ equals 1 and deviation variance $\left(s^{2} d_{i}\right)$ equals zero, then the hybrids were identified as stable. AMMI stability value (ASV) was estimated as the following formula [20]:

$$
\text { AMMI stability value }=\sqrt{\frac{\text { IPCA } 1 \text { sum of square }}{\text { IPCA } 2 \text { sum of square }} \text { score IPCA } 1=\text { score IPCA } 2} .
$$

Nonparametric stability of hybrids followed Nassar and Huehn [25], Huehn [26], Thennarasu [27], and Kang [28]. Nonparametric stability of Nassar and Huehn [25] and Huehn [26] was formulated as

$$
\begin{aligned}
S_{i}^{(1)} & =2 \sum_{j}^{n-1} \frac{\sum_{j^{\prime}=j+1}^{n}\left|r_{i j}-r_{i j}^{\prime}\right|}{[N(n-1)]}, \\
S_{i}^{(2)} & =\frac{\sum_{j=1}^{n}\left(r_{i j}-\bar{r}_{i .}\right)^{2}}{(N-1)}, \\
S_{i}^{(3)} & =\frac{\sum_{j=1}^{n}\left(r_{i j}-\bar{r}_{i .}\right)^{2}}{\bar{r}_{i .}}, \\
S_{i}^{(6)} & =\frac{\sum_{j=1}^{n}\left|r_{i j}-\bar{r}_{i .}\right|}{\bar{r}_{i .}},
\end{aligned}
$$

where $r_{i j}=$ rank of genotype $i$ in environment $j, \bar{r}_{i \text {. }}=$ rank of mean of the genotype in all environments, and $N=$ total environment.

Thennarasu [27] stability of $\mathrm{NP}^{(\mathrm{i})}$ was estimated using the following formula:

$$
\begin{aligned}
& N P^{(1)}=\frac{\sum_{j=1}^{n}\left|r_{i j}^{*}-M_{d i}^{*}\right|}{N}, \\
& N P^{(2)}=\frac{\left[\sum_{j=1}^{n}\left|r_{i j}^{*}-M_{d i}^{*}\right| / M_{d i}\right]}{N}, \\
& N P^{(3)}=\frac{\sqrt{\left(\sum\left(r_{i j}^{*}-r_{i .}^{*}\right)\right) / N}}{\bar{r}_{i .}}, \\
& N P^{(6)}=\frac{2 x\left[\sum_{j=1}^{n-1} \sum_{j^{\prime}=j+1}^{n}\left|r_{i j}^{*}-r_{i .}^{*}\right| / \bar{r}_{i .}\right]}{N(N-1)},
\end{aligned}
$$


where $r_{i j}^{*}=$ rank of genotype $i$ in environment $j$ based on adjusted data, $M_{d i}^{*}=$ rank of mean of the genotype based on adjusted data, $M_{d i}=$ parameter that was estimated based on unadjusted data, and $N=$ total environment.

Rank stability of Kr was estimated following Kang [28]. In this method, the weight of stable and high yield genotype is one. To estimate yield stability based on parametric and nonparametric methods, STABILITYSOFT software is used [30].

AMMI is based on the analysis of variance and principal component analysis (PCA) combined into a single model with additive and multiplicative parameters. Linear model of AMMI was described by Gauch and Zobel [31] as follows:

$$
Y_{\mathrm{ger}}=\mu+\alpha_{g}+\beta_{e}+\sum_{n} \lambda_{n} \gamma_{\mathrm{gn}} \delta_{\mathrm{en}}+\rho_{\mathrm{ge}}+\varepsilon_{\mathrm{ger}},
$$

where $\mu$ general mean, $\alpha_{g}=$ the genotype deviation, $\beta_{e}=$ the environment deviation, $\lambda_{n}=$ the singular value of component $n, \gamma_{\mathrm{gn}}=$ eigenvector of the genotype, $\delta_{\text {en }}=$ eigenvector of the environment, $\rho_{\mathrm{ge}}=$ residual, and $\varepsilon_{\text {ger }}=$ error.

GGE (genotype and genotype-environment Interaction) biplot was recommended by Yan et al. [20] as a modification of AMMI to select and to identify potential high-yield varieties which are stable and adaptive under multienvironment conditions. GGE biplot groups the additive of genotype effect in AMMI altogether with the interaction of $\mathrm{G} \times \mathrm{E}$ and analyzes of their effects by principal components. GGE biplot is more advanced than AMMI 1 and AMMI 2 mega-environment. GGE biplot explains the mean proportions of mean square of genotype + genotype $\times$ environment $(\mathrm{G}+\mathrm{GE})$. This explains why GGE biplot is more precise than AMMI 1 and more practical than AMMI 2 mega-environment $[32,33]$. GGE biplot model is described as follows [34]:

$$
Y_{h i j}=\mu+E_{h}+G_{i}+\mathrm{GE}_{h i}+B_{j(h)}+e_{h i j},
$$

where $\mu$ =population mean, $E_{h}=$ environmental effect, $G_{i}=$ genotypic effect, $\mathrm{GE}_{h i}=$ genotype-by-environment interaction effect, $B_{j(h)}=$ block effect, and $\mathrm{e}_{\mathrm{hij}}=$ random error. Biplots of AMMI and GGE were constructed from the general mean and IPCA score. Combined ANOVA, AMMI, and GGE analysis as well as their biplots were computed using STAR and PB Tools software developed by IRRI $[35,36]$.

\section{Results and Discussion}

Mean flowering and yield of new Indonesian sweet corn hybrids showed a broad range of variation in the six noticeable environments (Table 1). The earliest male flowering was in Wanayasa-season 1 (700 $\mathrm{m}$ asl.), whereas the longest male flowering was in Lembang-season 1 (950 m asl.). The highest grain yield was in Wanayasa-season 1, while the lowest grain yield was in Lembang-season 2 .

Sweet corn hybrids differed for male flowering and high yield due to their broad genetic base, distinct environment, and the interaction of $\mathrm{G} \times \mathrm{E}$. Genetic studies on flowering and yield and environment factors affecting their performance had been extensively studied [2, 37-39]. Many maize traits including flowering and yield are controlled by many genes and are inherited by quantitative genetic variations resulting from the combined action of multiple genes and environment [37]. The genetic architecture of flowering time and photoperiod sensitivity in maize are associated with 25 synthetic consensus QTL and four hotspot genomic regions [39]. However, architecture of the tassel was controlled by five candidate genes, namely, ramosa1 (ra1), barren inflorescence2 (bif2), unbranched2 (ub2), zea floricaula leafy2 (zfl2), and barren stalk fastigiate1 (baf1); thus, tassel size variation is inherited by maize photoperiod gene ZmCCT [39]. A major QTL (qTL9-1) for length of the tassel had been physically mapped to a $513 \mathrm{~kb}$ physical region [33]. This major QTL, clustered into a group of genes, contributes to the phenotypic variation for flowering time $[37,38]$.

The interaction of $\mathrm{G} \times \mathrm{E}$ plays an important rule for earliness and yield as well as genotype in this study (Table 2). From Table 2, it is shown that all hybrids express various responses in distinct environments. Many researchers supported the significant interaction of $\mathrm{G} \times \mathrm{E}$ for complex characters [10-12, 40,41]. As a complex trait, earliness and yield result from the interaction of a set of combinations of the biochemistry reaction from many genes and environments such as soil structure and fertility, rain, temperature of soil and air, and the interaction of $\mathrm{G} \times \mathrm{E}$ [19]. The interaction of $\mathrm{G} \times \mathrm{E}$ is the source of inconsistency for earliness and yield performance of sweet corn hybrids in various test locations. In a specific environment, superior hybrids are able to minimize the effect of negative factors in that environment but at the same time can maximize the effect of positive factors in the environment resulting in high yield of hybrid performance. Based on this study, it is possible to develop high-yield sweet corn hybrids for specific locations and seasons.

Nonparametric stability and parametric stability for earliness and yield are presented in Table 3. Based on the parametric stability of earliness in Table 3, most hybrids in the current study showed higher $b$ values, indicating better adaptability of these hybrids to high-yielding environments [29]. It is shown that sweet corn hybrids SR $33 \times$ SR 17, G11, with $b=1.01$, and SR $24 \times$ SR 17, G5, with $b=0.99$, have slopes nearest to 1.00 among the 18 hybrids in the data set, whereas for the yield character, sweet corn hybrid SR $31 \mathrm{x}$ SR 17 , G9, with $b=0.99$, has slope nearest to 1.00 among the 18 hybrids in the data set. On this criteria, hybrids G11 and G5 would be selected as the most stable of the 18 earliness hybrids over the 6 environments in this multilocation and season test, whereas, hybrid G9 would be selected as the most stable of the 18 high-yield hybrids. Furthermore, these hybrids have the smallest deviation from regression on site index. This is measured by the deviation mean square of $s^{2} d_{i}$ of all hybrids for earliness and yield. Sweet corn hybrid G5, SR 24 x SR 17, on the contrary, performs to be adapted to better environments. This is confirmed by the slope for this hybrid, $b=1.27$, which is greater than 1 and also showed the highest grain yield out of 18 hybrids over 6 environments. 
TABLE 1: Range, mean, and standard deviation of sweet corn hybrids for flowering and yield.

\begin{tabular}{lcccc}
\hline \multirow{2}{*}{ Locations } & \multicolumn{2}{c}{ Male flowering (days after planting) } & \multicolumn{2}{c}{ Yield (ton/ha) } \\
& Range & Mean \pm std dev & Range & Mean \pm std dev \\
\hline Jatinangor-season 1 & $60-74$ & $66.44 \pm 3.68$ & $7.89-20.69$ & $13.06 \pm 2.96$ \\
Jatinangor-season 2 & $57-70$ & $65.54 \pm 2.23$ & $8.55-18.19$ & $12.84 \pm 2.21$ \\
Lembang-season 1 & $76-78$ & $76.07 \pm 0.33$ & $8.77-19.23$ & $13.32 \pm 2.52$ \\
Lembang-season 2 & $69-83$ & $75.22 \pm 3.33$ & $3.54-17.19$ & $7.85 \pm 2.86$ \\
Wanayasa-season 1 & $56-67$ & $63.00 \pm 1.43$ & $7.31-22.99$ & $14.65 \pm 3.08$ \\
Wanayasa-season 2 & $57-66$ & $62.46 \pm 2.06$ & $6.80-15.31$ & $10.48 \pm 1.75$ \\
\hline
\end{tabular}

TABLE 2: Combined analysis of variance for earliness and yield of sweet corn hybrids.

\begin{tabular}{lccc}
\hline Source & DF & $\begin{array}{c}\text { Male flowering } \\
\text { Mean square }\end{array}$ & $\begin{array}{c}\text { Yield } \\
\text { Mean square }\end{array}$ \\
\hline Environment $(\mathrm{E})$ & 5 & $1959.1679^{* *}$ & $325.2384^{* *}$ \\
Hybrids $(\mathrm{G})$ & 17 & $16.9317^{* *}$ & $11.7243^{* *}$ \\
Hybrids $\times$ environment $(\mathrm{G} \times \mathrm{E})$ & 85 & $7.8202^{* *}$ & $9.8468^{* *}$ \\
Pooled error & 204 & 4.0294 & 3.7728 \\
\hline
\end{tabular}

${ }^{* *},{ }^{*}$ and ns: significant at the 0.01 and 0.05 probability levels, respectively, and nonsignificant.

TABLe 3: Stability of earliness and yield based on nonparametric and parametric methods.

\begin{tabular}{|c|c|c|c|c|c|c|c|c|c|c|c|c|c|}
\hline Genotype & MFL & $S^{(1)}$ & $S^{(2)}$ & $S^{(3)}$ & $\mathrm{S}^{(6)}$ & $\mathrm{NP}^{(1)}$ & $\mathrm{NP}^{(2)}$ & $\mathrm{NP}^{(3)}$ & $\mathrm{NP}^{(4)}$ & $\mathrm{R}$ & $\mathrm{s}^{2} \mathrm{~d}_{\mathrm{i}}$ & $b_{i}$ & ASV \\
\hline SR4 x SR17 & 68.56 & 8.00 & 43.87 & 21.23 & 3.29 & 4.33 & 0.49 & 0.44 & 0.77 & 14.00 & 0.83 & 1.02 & 0.99 \\
\hline SR9 $\times$ SR17 & 68.61 & 7.53 & 1.79 & 33.15 & 4.62 & 3.83 & 1.21 & 0.85 & 1.16 & 24.00 & 6.64 & 0.81 & 4.00 \\
\hline SR15 x SR17 & 67.72 & 0.29 & 34.27 & 22.35 & 3.91 & 4.67 & 0.89 & 0.75 & 0.94 & 28.00 & 2.22 & 0.95 & 1.94 \\
\hline SR22 x SR17 & 69.06 & 8.73 & 50.57 & 24.87 & 3.44 & 0.21 & 0.56 & 0.58 & 0.86 & 12.00 & 1.07 & 1.07 & 1.13 \\
\hline SR24 x SR17 & 68.56 & 5.53 & 21.77 & 12.32 & 2.42 & 2.00 & 0.37 & 0.25 & 0.63 & 10.00 & 0.16 & 0.99 & 0.38 \\
\hline SR25 x SR17 & 67.33 & 4.27 & 12.67 & 14.62 & 3.85 & 4.00 & 2.76 & 1.28 & 0.98 & 25.00 & 1.44 & 1.10 & 1.16 \\
\hline SR26 x SR17 & 69.89 & 4.87 & 0.80 & 6.86 & 1.52 & 5.17 & 0.56 & 0.39 & 0.34 & 15.00 & 2.14 & 1.01 & 1.73 \\
\hline SR30 x SR17 & 67.89 & 0.17 & 0.59 & 13.00 & 3.27 & 2.33 & 1.00 & 0.55 & 0.84 & 14.00 & 0.25 & 0.96 & 0.35 \\
\hline SR31 x SR17 & 67.28 & 7.27 & 37.37 & 27.34 & 4.54 & 4.83 & 1.58 & 0.93 & 1.06 & 32.00 & 4.06 & 1.09 & 2.96 \\
\hline SR32 x SR17 & 68.67 & 6.67 & 30.27 & 13.35 & 2.47 & 4.33 & 0.43 & 0.41 & 0.59 & 11.00 & 0.68 & 0.97 & 1.04 \\
\hline SR33 x SR17 & 68.22 & 0.17 & 13.77 & 11.16 & 2.76 & 1.33 & 0.59 & 0.31 & 0.75 & 11.00 & 0.09 & 1.01 & 0.34 \\
\hline SR41 x SR17 & 67.11 & 3.47 & 10.67 & 14.55 & 3.64 & 4.83 & 3.53 & 1.44 & 0.95 & 29.00 & 1.31 & 1.13 & 1.85 \\
\hline SR43 x SR17 & 69.00 & 6.33 & 30.17 & 13.92 & 2.12 & 3.00 & 0.45 & 0.34 & 0.58 & 8.00 & 0.30 & 0.95 & 0.48 \\
\hline SR46 x SR17 & 69.11 & 7.13 & 34.97 & 17.20 & 2.49 & 4.17 & 0.52 & 0.50 & 0.70 & 15.00 & 1.66 & 0.90 & 2.01 \\
\hline SR47 x SR17 & 67.83 & 5.00 & 0.71 & 13.46 & 2.77 & 3.67 & 0.69 & 0.65 & 0.77 & 17.00 & 0.59 & 1.02 & 0.73 \\
\hline SR52 x SR17 & 68.44 & 7.13 & 34.17 & 16.80 & 2.66 & 2.83 & 0.39 & 0.33 & 0.70 & 17.00 & 0.94 & 0.99 & 1.31 \\
\hline SB & 65.72 & 0.13 & 0.54 & 22.00 & 5.33 & 0.25 & 4.33 & 2.39 & 0.04 & 34.00 & 3.44 & 1.00 & 1.83 \\
\hline BS & 67.22 & 4.93 & 0.71 & 0.71 & 4.00 & 4.83 & 1.88 & 1.14 & 0.99 & 26.00 & 1.37 & 1.03 & 0.73 \\
\hline Genotype & GY & $S^{(1)}$ & $S^{(2)}$ & $S^{(3)}$ & $S^{(6)}$ & $\mathrm{NP}^{(1)}$ & $\mathrm{NP}^{(2)}$ & $\mathrm{NP}^{(3)}$ & $\mathrm{NP}^{(4)}$ & $\mathrm{R}$ & $\mathrm{s}^{2} \mathrm{~d}_{\mathrm{i}}$ & $b_{i}$ & ASV \\
\hline SR4 x SR17 & 11.99 & 7.20 & 34.27 & 20.56 & 3.60 & 4.50 & 0.63 & 0.58 & 0.86 & 20.00 & 1.32 & 1.30 & 1.18 \\
\hline SR9 x SR17 & 11.99 & 6.73 & 31.37 & 17.11 & 2.98 & 4.33 & 0.56 & 0.60 & 0.73 & 17.00 & 1.33 & 1.24 & 1.02 \\
\hline SR15 x SR17 & 12.44 & 6.80 & 32.00 & 14.55 & 2.36 & 4.33 & 0.39 & 0.49 & 0.62 & 12.00 & 0.87 & 0.65 & 0.75 \\
\hline SR22 x SR17 & 11.65 & 3.67 & 9.37 & 5.73 & 1.59 & 2.67 & 0.29 & 0.39 & 0.45 & 17.00 & 0.61 & 0.93 & 0.46 \\
\hline SR24 x SR17 & 13.56 & 3.87 & 10.00 & 3.57 & 1.00 & 3.83 & 0.41 & 0.36 & 0.28 & 16.00 & 1.63 & 1.27 & 1.06 \\
\hline SR25 x SR17 & 12.12 & 7.33 & 35.47 & 19.00 & 3.00 & 4.83 & 0.59 & 0.59 & 0.79 & 18.00 & 1.54 & 1.20 & 1.19 \\
\hline SR26 x SR17 & 11.63 & 5.67 & 22.57 & 11.47 & 1.97 & 3.67 & 0.40 & 0.50 & 0.58 & 31.00 & 3.20 & 0.58 & 1.69 \\
\hline SR30 x SR17 & 11.87 & 3.87 & 11.07 & 5.93 & 1.79 & 2.33 & 0.33 & 0.28 & 0.41 & 13.00 & 0.48 & 0.83 & 0.47 \\
\hline SR31 x SR17 & 12.59 & 4.20 & 11.50 & 5.00 & 1.48 & 1.83 & 0.25 & 0.23 & 0.37 & 4.00 & 0.19 & 0.99 & 0.12 \\
\hline SR32 x SR17 & 12.09 & 6.60 & 29.77 & 15.14 & 2.75 & 4.17 & 0.41 & 0.46 & 0.67 & 13.00 & 0.78 & 0.83 & 0.22 \\
\hline SR33 x SR17 & 12.34 & 7.67 & 43.90 & 19.09 & 2.87 & 5.33 & 0.39 & 0.53 & 0.67 & 18.00 & 1.21 & 0.59 & 1.35 \\
\hline SR41 x SR17 & 11.44 & 6.60 & 28.97 & 20.21 & 3.77 & 5.00 & 0.69 & 0.71 & 0.92 & 27.00 & 1.54 & 1.19 & 1.00 \\
\hline SR43 x SR17 & 11.67 & 7.73 & 39.20 & 21.78 & 3.33 & 5.00 & 0.63 & 0.63 & 0.86 & 27.00 & 3.74 & 1.17 & 1.51 \\
\hline SR46 x SR17 & 11.80 & 4.33 & 13.50 & 7.94 & 2.12 & 2.83 & 0.28 & 0.41 & 0.51 & 13.00 & 0.33 & 1.12 & 0.39 \\
\hline SR47 x SR17 & 11.63 & 6.13 & 25.87 & 15.52 & 3.12 & 4.67 & 0.46 & 0.61 & 0.74 & 21.00 & 1.31 & 1.00 & 0.91 \\
\hline SR52 x SR17 & 11.51 & 5.40 & 22.57 & 14.40 & 2.89 & 3.83 & 0.64 & 0.58 & 0.69 & 21.00 & 0.44 & 0.70 & 0.56 \\
\hline SB & 14.01 & 8.67 & 55.20 & 25.09 & 3.64 & 8.33 & 0.58 & 0.76 & 0.79 & 19.00 & 3.06 & 2.09 & 2.78 \\
\hline BS & 10.31 & 8.80 & 61.60 & 44.00 & 5.71 & 5.67 & 2.39 & 0.91 & 1.26 & 35.00 & 4.99 & 0.30 & 2.55 \\
\hline
\end{tabular}

$\mathrm{MFL}=$ earliness, $\mathrm{GY}=$ grain yield; $\mathrm{S}^{(1)}, \mathrm{S}^{(2)}, \mathrm{S}^{(3)}$, and $\mathrm{S}^{(6)}=$ nonparametric stability of Nassar and Huehn [25] and Huehn [26]; $\mathrm{NP}^{(1)}, \mathrm{NP}^{(2)}, \mathrm{NP}^{(3)}$, and $\mathrm{NP}^{(4)}=$ nonparametric stability of Thennarasu [27]; $\mathrm{R}=$ nonparametric stability of Kang [28]; $\mathrm{s}^{2} \mathrm{~d}_{\mathrm{i}}=$ standard deviation parametric stability of Eberhart and Russell [29], $b_{i}=$ regression coefficient parametric stability of Eberhart and Russell [29]; and ASV = AMMI stability value [20]. 
Nonparametric stability estimation of sweet corn hybrids of $\mathrm{S}^{(\mathrm{i})}, \mathrm{NP}^{(\mathrm{i})}$, and $\mathrm{KR}$ is also presented in Table 3. Based on stability parameters of $S^{(} \mathrm{i}^{\prime}, \mathrm{NP}^{(\mathrm{i})}$, and $\mathrm{KR}$, it was showed that sweet corn hybrids G5, G8, and G11, for earliness, and G5, G9, and G11, for yield, have the lowest values among the 18 hybrids [25-28]. These hybrids represented the most stable hybrids over 6 environments in multilocation and season tests. On these criteria, hybrids G5 and G9 would be selected as the most stable out of the 18 earliness and yield hybrids over 6 environments in this multilocation and season tests. Based on criteria of parametric and nonparametric stability for earliness and yield, hybrids G5 and G9 showed the lowest average rank of stability (Supplemental Table 1 and Supplemental Table 2.).

The ASV of 18 sweet corn hybrids is presented in Table 3. The ASV of the hybrids ranged from 0.35 to 4.00 for earliness and from 0.12 to 2.78 for yield. Hybrids G5 (0.38), G9 (0.35), and G11 (0.34) were the most stable with low ASV values for earliness, whereas hybrids G4 (0.46), G9 (0.47), and G11 (0.12) were the most stable with low ASV values for yield. Hybrid G9 is seen to be stable for earliness and yield. Based on the criteria of parametric and nonparametric stability and multivariate parameter of the ASV, it is seen that hybrids G5 and G11 were the most stable hybrids with the most earliness and the highest yield. This result was similar to the study by previous researchers $[6,41,42]$ that revealed the stable genotype with low average rank of parametric and nonparametric stability with high grain yield.

In Table 4, AMMI analysis revealed the significant accumulation percentage of mean square for the first interaction principal component axis (IPCA-1) and the second interaction principal component axis (IPCA-2) as follows: $63.1 \%$ and $80.0 \%$ and $51.4 \%$ and $81.7 \%$ for male flowering and yield, respectively. On the contrary, GGE analysis revealed similar significant accumulation percentage of mean square for IPCA-1 and IPCA- 2 as follows: $55.6 \%$ and $82.5 \%$ and $53.3 \%$ and $79.6 \%$ for male flowering and yield, respectively (Table 5). AMMI for the yield of Indonesian sweet corn hybrids in six distinct environments revealed that $5.26 \%$ of total mean square (MS) was contributed from the genotype. Around $42.98 \%$ of total MS was due to environment (locations and seasons), and $22.12 \%$ was due to the interaction of $\mathrm{G} \times \mathrm{E}$. This result revealed that sweet corn hybrids express various responses for male flowering and yield due to their broad base genetic background and the interaction of $\mathrm{G} \times \mathrm{E}$ by locations and seasons.

The AMMI biplot revealed a graphic appearance of the association between IPCA-1, IPCA-2, and G and E (Figures 1(a) and 1(b)). Hybrids in sections II and III of the biplot showed average male flowering longer than the grand mean, whereas hybrids in sections I and IV had mean male flowering shorter than the grand mean. On the contrary, the male flowering hybrids in sections II and III showed average grain yields higher than the grand mean, whereas hybrids in sections I and IV exhibited average grain yields lower than the grand mean. Hybrids that were adjacent to the starting point of IPCA-1 expressed low contribution to the IGE; therefore, these hybrids are stable in all test locations and seasons.
TABLE 4: AMMI analysis for earliness and yield of sweet corn in West Java.

\begin{tabular}{lccccccc}
\hline $\begin{array}{l}\text { Source of } \\
\text { variance }\end{array}$ & \multirow{4}{*}{ DF } & \multicolumn{3}{c}{ Male flowering } & \multicolumn{3}{c}{ Yield } \\
& & Mean sq. & $\%$ & Acum & Mean sq. & $\%$ & Acum \\
\hline PC1 & 21 & $19.9659^{* *}$ & 63.1 & 63.1 & $20.4987^{* *}$ & 51.4 & 51.4 \\
PC2 & 19 & $5.9006^{*}$ & 16.9 & 80.0 & $13.3296^{* *}$ & 30.3 & 81.7 \\
PC3 & 17 & $4.0663 \mathrm{~ns}$ & 10.4 & 90.4 & $5.1804^{*}$ & 10.5 & 92.2 \\
PC4 & 15 & $3.3336 \mathrm{~ns}$ & 7.5 & 97.9 & $2.2774 \mathrm{~ns}$ & 4.1 & 96.3 \\
PC5 & 13 & $1.0910 \mathrm{~ns}$ & 2.1 & 100.0 & $2.3855 \mathrm{~ns}$ & 3.7 & 100.0 \\
PC6 & 11 & $0.0000 \mathrm{~ns}$ & 0.0 & 100.0 & $0.0000 \mathrm{~ns}$ & 0.0 & 100.0 \\
\hline
\end{tabular}

${ }^{* *},{ }^{*}$ and ns: significant at the 0.01 and 0.05 probability levels, respectively, and nonsignificant.

TABLE 5: GGE biplot analysis for earliness and yield of sweet corn hybrids in West Java.

\begin{tabular}{lccccccc}
\hline $\begin{array}{l}\text { Source of } \\
\text { variance }\end{array}$ & \multirow{2}{*}{ DF } & \multicolumn{3}{c}{ Male flowering } & \multicolumn{3}{c}{ Yield } \\
& & Mean sq. & $\%$ & Acum & Mean sq. & $\%$ & Acum \\
\hline PC1 & 21 & $25.2236^{* *}$ & 55.6 & 55.6 & $26.3239^{* *}$ & 53.3 & 53.3 \\
PC2 & 19 & $13.4791^{* *}$ & 26.9 & 82.5 & $14.3307^{* *}$ & 26.3 & 79.6 \\
PC3 & 17 & $4.7578 \mathrm{~ns}$ & 8.5 & 91.0 & $6.0466^{*}$ & 9.9 & 89.5 \\
PC4 & 15 & $4.2246 \mathrm{~ns}$ & 6.7 & 97.7 & $4.1606 \mathrm{~ns}$ & 6.0 & 95.5 \\
PC5 & 13 & $1.6115 \mathrm{~ns}$ & 2.2 & 99.9 & $2.5247 \mathrm{~ns}$ & 3.2 & 98.7 \\
PC6 & 11 & $0.1409 \mathrm{~ns}$ & 0.2 & 100.1 & $1.1982 \mathrm{~ns}$ & 1.3 & 100.0 \\
\hline
\end{tabular}

${ }^{* *},{ }^{*}$ and ns: significant at the 0.01 and 0.05 probability levels, respectively, and nonsignificant.

Hybrids found above 1 or -1 performed a high interactive response with locations and seasons nearby and were unstable. In the same way, locations and seasons with IPCA1 values close to the starting point showed low interaction with hybrids and thus showed low distinction of hybrids. Most hybrids showed PC1 between 1 and -1 ; similarly, environment had PC1 between 1 and -1 both for male flowering and grain yield. G5, G8, G11, and G14 were close to zero and, therefore, were stable hybrids for male flowering. G9 and G10 were also near to zero and were stable hybrids for grain yield. High response of male flowering to environments was shown by G3 (+1) for Jatinangor (E2), Lembang (E3), and Wanayasa (E5); G9 (+2) for Lembang (E4) and Wanayasa (E6); and G18 (-2) for Jatinangor (E1). On the contrary, high response of grain yield to environments was shown by G2 (+2) for Jatinangor (E1), Lembang (E3), and Wanayasa (E5) and G1 (+2) for Jatinangor (E2), Lembang (E4), and Wanayasa (E6).

A GGE biplot in which hybrids had won and in which locations and seasons were drawn using IPCA-1 and IPCA-2 values for both hybrids and locations and seasons is shown in Figures 2(a) and 2(b). The GGE biplot showed that hybrids G4, G7, G18, G2, and G9 were the uppermost from the starting point and performed a high response $( \pm)$ with particular locations and seasons for male flowering (Figure 2(a)). Hybrids G14, G2, G5, G7, and G1 were found at the outermost from the starting point and showed a high response $( \pm)$ with specific locations and seasons for grain yield (Figure 2(b)).

A polygon was drawn by connecting the outermost hybrids with lines. Lines upright to the edges of the polygon 
AMMI biplot for MFL

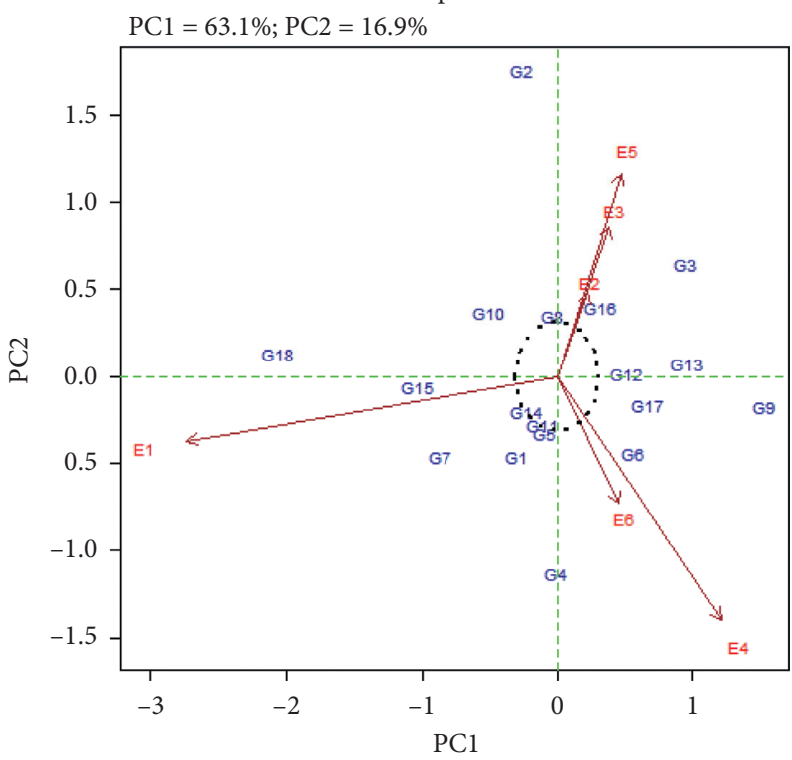

(a)

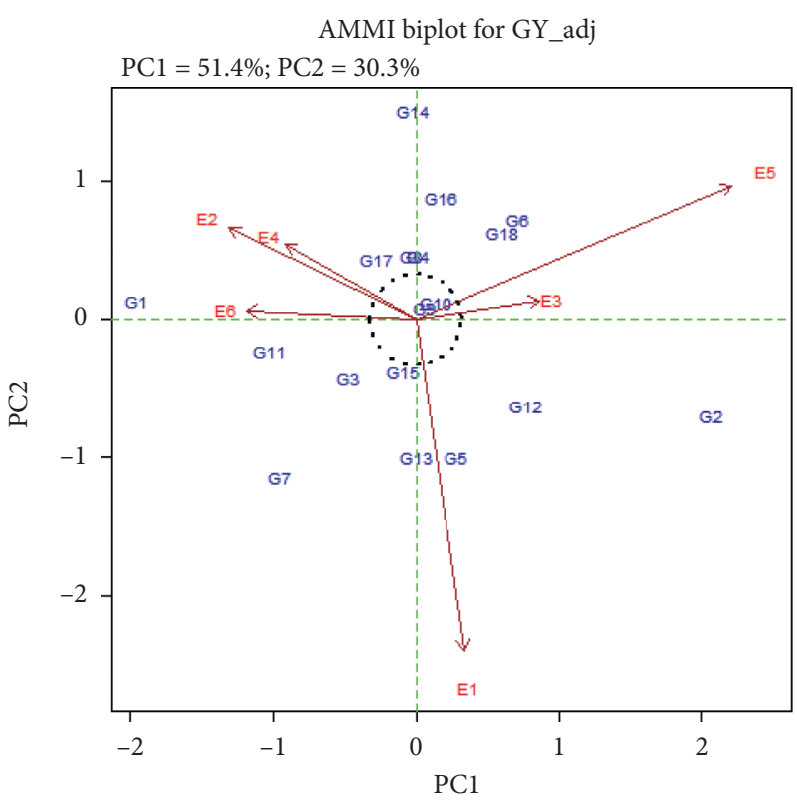

(b)

FIgURE 1: AMMI-2 biplot: (a) male flowering; (b) grain yield.

What-won-where biplot for MFL

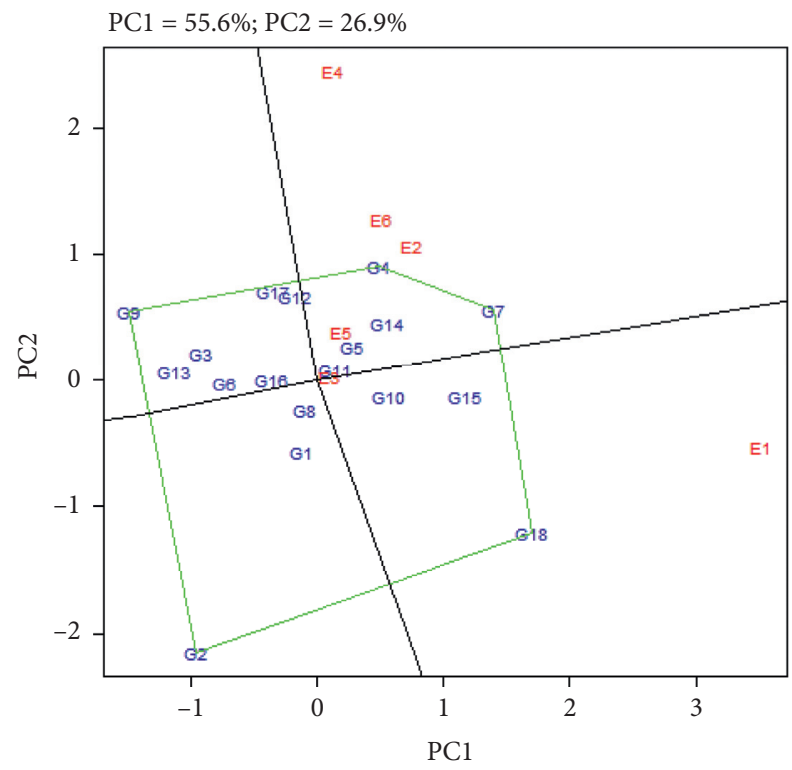

(a)
What-won-where biplot for GY_adj

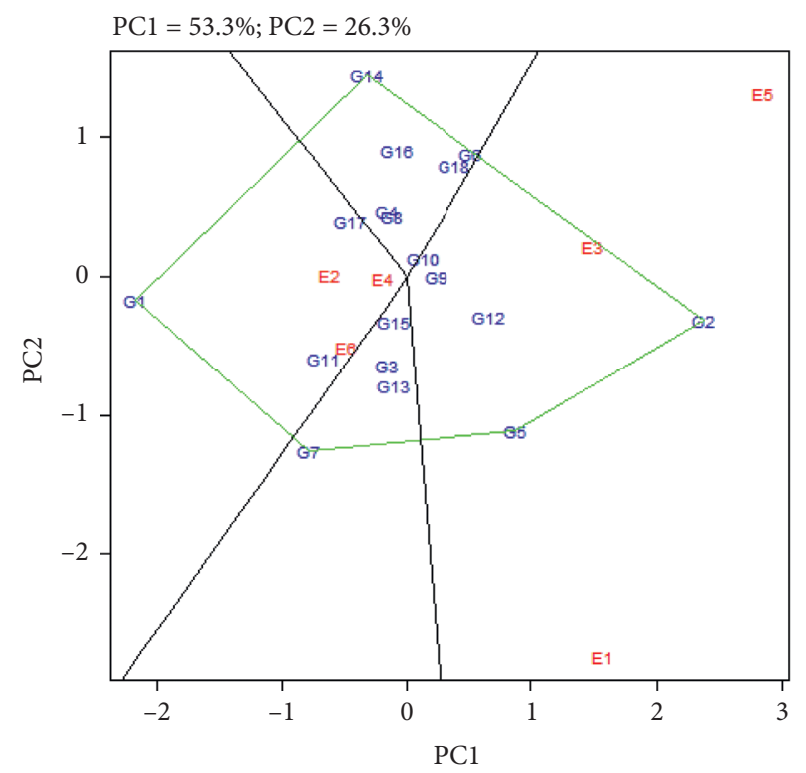

(b)

Figure 2: GGE biplot: (a) male flowering; (b) grain yield.

were connected and these shaped four sections of which only one showed environment undoubtedly appointed to a hybrid at the high point of the polygon. In this study, E2, E3, E4, E5, and E6 were in sector one, and the summit hybrids were G4 (+) and G7 (+), which were the longer male flowering hybrids in these environments. G5 and G14 were hybrids in sector one and also showed long male flowering. E1 was in sector two, and the summit hybrid was G18 (+), which was the longest male flowering hybrid in these environments. E5, E3, and E1 were in sector one, and the peak hybrids were G2 (+) and G5 (+), which were the highest yield hybrids in these environments. G9, G10, and G12 were also in section one and performed high yield. E2, E4, and E6 were in sector three, and the summit hybrid was G1 (-), which was the highest yield hybrid in this environment. 


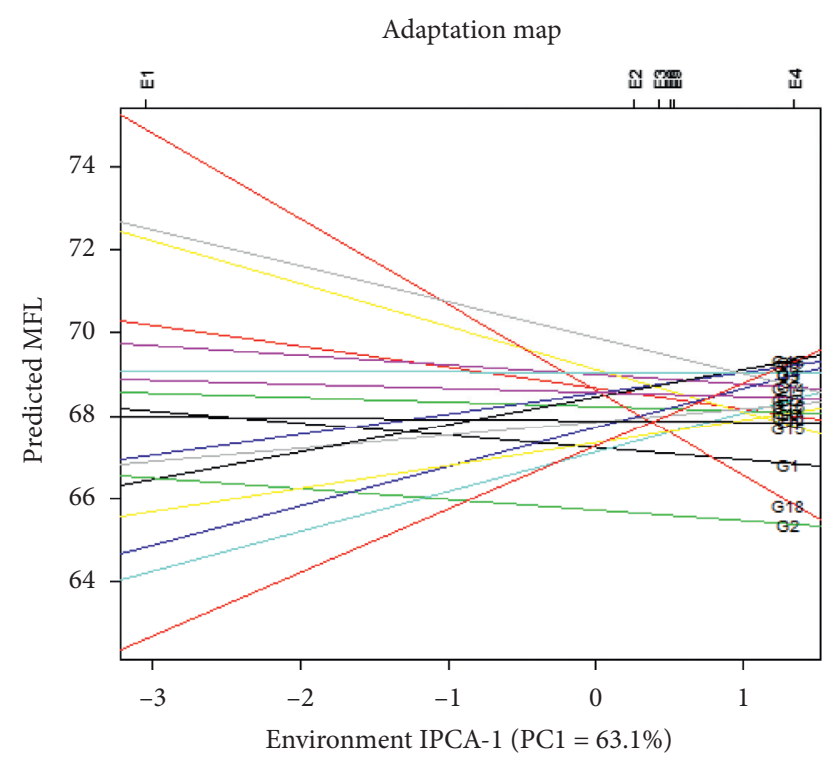

(a)

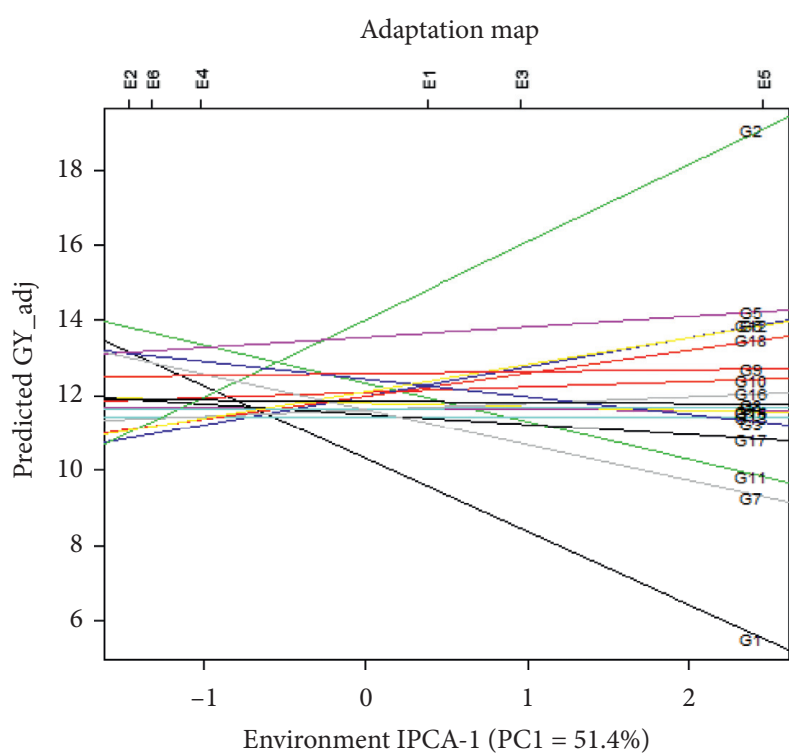

(b)

FIGURE 3: Adaptation map of Indonesian sweet corn for (a) male flowering (dap: days after planting) and (b) grain yield (ton/ha).

Using the polygon GGE biplot, some researchers located superior genotypes and environments in at least four regions in which the farthest hybrids were drawn into a polygon $[7,18,21,22,41]$. The number of regions in the polygons is due to the diverse genetic background of genotypes and distinct environments involved. Chimonyo et al. [43] reported seven sectors of the polygon in which the extreme South African maize genotype as vertex were PAN 6479, Okavango, ZM627, BR993, Afric 1, COMP 4, and Obatanpa. On the other hand, the distinct environment were only in three sectors. They were five environments from sector one, three environments from sector two, and two environments from sector three. HoyosVillegas et al. [7] stated six sectors of the polygon which have different genetic-background of the beans as a summit. These summit genotypes were Topaz of Durango, Verano of Measoamerica, TARS-VCI-48 of Admixed, PR0340-3-3-1 of Mesoamerica, PT7-2 of Durango, and Merlot, Lapz and Sedona of Admixed. On the other hand, the distinct environment involved was MRC from the sector with Merlot, La $\mathrm{Paz}$, and Sedona as the summits, SVREC1 from the sector with PT7-2 as the summit, and SVRECR from the sector with PR0340-2-1 as the summit.

An adaptation biplot was drawn using IPCA-1, grand mean of male flowering (Figure 3(a)), and grain yield for both hybrids and environments (Figure 3(b)). G5 (SR 24 x SR 17) was a high-response hybrid for grain yield to Jatinangor (E1, $\mathrm{E} 2)$, Lembang (E3, E4), and Wanayasa (E5, E6), as well as short male flowering to Jatinangor (E2), Lembang (E3, E4), and Wanayasa (E5, E6). G11 (SR 33 x SR 17) showed high yield as a response to Jatinangor (E2) and Wanayasa (E6).

In Indonesia, farmers are interested to cultivate hybrids showing high yield and stable hybrids. Similar to this condition, Chimonyo et al. [43] mentioned that farmers in Africa preferred to select superior maize adapted to a specific or broad environment to protect their yield and economic revenue that was influenced by environment change. Therefore, G5 could be selected to be cultivated in West Java, Indonesia, since it showed stable high yield and earliness in the three distinct locations for two different seasons.

\section{Conclusion}

This study identified the most promising sweet corn hybrids including hybrids G5 (SR 24 x SR 17) and G11 (SR 31 x SR 17). The parametric and nonparametric stability parameters and ASV were complement to the AMMI and GGE biplots in selecting stable and adaptable hybrids in terms of earliness and yield. G5 was selected as a high-response hybrid for grain yield to Jatinangor (E1, E2), Lembang (E3, E4), and Wanayasa (E5, E6), as well as earliness to Jatinangor (E2), Lembang (E3, E4), and Wanayasa (E5, E6). G5 sweet corn hybrid, therefore, is suggested to be extensively evaluated on farm and produced for smallholder farmers in West Java, Indonesia.

\section{Data Availability}

All data generated or analysed to support the findings of this study are included in this published article and its supplementary information files.

\section{Conflicts of Interest}

The authors declare that there are no conflicts of interest regarding the publication of this paper.

\section{Acknowledgments}

This research was funded by the University of Padjadjaran (nos. 18/UN6.E/LT/2018 and 005/UN6.E/LT/2019). 


\section{Supplementary Materials}

Supplemental Table 1: rank of stability for earliness based on nonparametric and parametric methods. Supplemental Table 2: rank of stability for yield based on nonparametric and parametric methods. (Supplementary Materials)

\section{References}

[1] D. Ruswandi, J. Supriatna, N. Rostini, and E. Suryadi, "Assessment of sweetcorn hybrids under sweetcorn/chilli pepper intercropping in West Java, Indonesia," Journal of Agronomy, vol. 15, no. 3, pp. 94-103, 2016.

[2] E. S. Mace, C. H. Hunt, and D. R. Jordan, "Supermodels: sorghum and maize provide mutual insight into the genetics of flowering time," Theoretical and Applied Genetics, vol. 126, no. 5, pp. 1377-1395, 2013.

[3] M. Balestre, J. C. Souza, R. G. V. Pinho, R. L. Oliveira, and J. M. V. Paes, "Yield stability and adaptability of maize hybrids based on GGE biplot analysis characteristics," Cropp Breeding and Applied Biotechnology, vol. 9, no. 3, pp. 219-228, 2009.

[4] L. C. I. D. Silveira, V. Kist, T. O. M. D. Paula et al., "AMMI analysis to evaluate the adaptability and phenotypic stability of sugarcane genotypes," Scientia Agricola, vol. 70, no. 1, pp. 27-32, 2013.

[5] B. Vaezi, A. Pour-Aboughadareh, R. Mohammadi et al., "GGE Biplot and AMMI analysis of barley yield performance in Iran," Cereal Research Communications, vol. 45, no. 3, pp. 500-511, 2017.

[6] B. Vaezi, A. Pour-Aboughadareh, R. Mohammadi et al., "Integrating different stability models to investigate genotype $\times$ environment interactions and identify stable and highyielding barley genotypes," Euphytica, vol. 215, no. 63, 2019.

[7] V. Hoyos-Villegas, E. M. Wright, and J. D. Kelly, "GGE biplot analysis of yield associations with root traits in a mesoamerican bean diversity panel," Crop Science, vol. 56, no. 3, pp. 1081-1094, 2016.

[8] F. Flores, M. Hybl, J. C. Knudsen et al., "Adaptation of spring faba bean types across European climates," Field Crops Research, vol. 145, pp. 1-9, 2013.

[9] T. Temesgen, G. Keneni, T. Sefera, and M. Jarso, "Yield stability and relationships among stability parameters in faba bean (Vicia faba L.) genotypes," The Crop Journal, vol. 3, no. 3, pp. 258-268, 2015.

[10] B. Badu-Apraku, M. Oyekunle, A. Menkir et al., "Comparative performance of early-maturing maize cultivars developed in three eras under drought stress and well-watered environments in West Africa," Crop Science, vol. 53, no. 4, pp. 1298-1311, 2013.

[11] B. Badu-Apraku, M. A. B. Fakorede, M. Oyekunle et al., "Gains in grain yield of early maize cultivars developed during three breeding eras under multiple environments," Crop Science, vol. 55, no. 2, pp. 527-539, 2015.

[12] B. Badu-Apraku, M. A. B. Fakorede, A. O. Talabi et al., "Gene action and heterotic groups of early white quality protein maize inbreds under multiple stress environments," Crop Science, vol. 56, no. 1, pp. 183-199, 2016.

[13] M. Mushayi, H. Shimelis, J. Derera, A. I. T. Shayanowako, and I. Mathew, "Multi-environmental evaluation of maize hybrids developed from tropical and temperate lines," Euphytica, vol. 216, no. 84, 2020.

[14] E. J. D. Oliveira, J. P. X. D. Freitas, and O. N. D. Jesus, “AMMI analysis of the adaptability and yield stability of yellow passion fruit varieties," Scientia Agricola, vol. 71, no. 2, pp. 139-145, 2014.

[15] A. Akter, M. Jamil Hasan, M. U. Kulsum et al., "Genotype $\times$ environment interaction and yield stability analysis in hybrid rice (Oryza sativa L.) by AMMI biplot," Bangladesh Rice Journal, vol. 19, no. 1, pp. 83-90, 2015.

[16] K. Rak, F. M. Navarro, and J. P. Palta, "Genotype $\times$ storage environment interaction and stability of potato chip color: implications in breeding for cold storage chip quality," Crop Science, vol. 53, no. 5, pp. 1944-1952, 2013.

[17] R. van der Merwe, M. T. Labuschagne, L. Herselman, and A. Hugo, "Stability of seed oil quality traits in high and midoleic acid sunflower hybrids," Euphytica, vol. 193, no. 2, pp. 157-168, 2013.

[18] C. Aruna, S. Rakshit, P. K. Shrotria et al., "Assessing genotypeby-environment interactions and trait associations in forage sorghum using GGE biplot analysis," The Journal of Agricultural Science, vol. 154, no. 1, pp. 73-86, 2016.

[19] D. Castillo, I. Matus, A. del Pozo, R. Madariaga, and M. Mellado, "Adaptability and genotype $\mathrm{x}$ environment interaction of spring wheat cultivars in Chile using regression analysis, AMMI, and SRAG," Chilean Journal of Agricultural Research, vol. 72, no. 2, pp. 167-174, 2012.

[20] W. Yan, L. A. Hunt, Q. Sheng, and Z. Szlavnics, "Cultivar evaluation and mega-environment investigation based on the GGE biplot," Crop Science, vol. 40, no. 3, pp. 597-605, 2000.

[21] E. Farshadfar, H. Zali, and R. Mohammadi, "Evaluation of phenotypic stability in chickpea genotypes using GGEBiplot," Annals of Biological Research, vol. 2, no. 6, pp. 282292, 2011.

[22] P. S. Rao, B. Rathore, B. V. S. Reddy, and S. Panvar, “Application GGE biplot and AMMI model to evaluate sweet sorghum (Sorghum bicolor) hybrids for genotype $\times$ environment interaction and seasonal adaptation," Indian Journal of Agricultural Sciences, vol. 81, no. 5, pp. 438-444, 2011.

[23] N. M. R. Rad, M. Abdul Kadir, M. Y. Rafii, H. Z. E. Jaafar, M. R. Naghavi, and F. Ahmadi, "Genotype $\times$ environment interaction by AMMI and GGE biplot analysis in three consecutive generations of wheat (Triticum aestivum) under normal and drought stress conditions," AJCS, vol. 7, no. 7, pp. 956-961, 2013.

[24] K. A. Gomez and A. A. Gomez, Prosedur Statistik Untuk Penelitian Pertanian. Edisi Kedua, UI-Press, Iowa City, IA, USA, 1995.

[25] R. Nassar and M. Huhn, "Studies on estimation of phenotypic stability: tests of significance for nonparametric measures of phenotypic stability," Biometrics, vol. 43, no. 1, pp. 45-53, 1987.

[26] M. Huehn, "Nonparametric measures of phenotypic stability: Part 1: 94 Theory," Euphytica, vol. 47, pp. 189-194, 1990.

[27] K. Thennarasu, "On certain non-parametric procedures for studying genotype-environment interactions and yield stability," 1995.

[28] M. S. Kang, "A rank-sum method for selecting high-yielding, stable corn genotypes," Cereal Research Communications, vol. 16, pp. 113-115, 1988.

[29] S. A. Eberhart and W. A. Russell, "Stability parameters for comparing varieties 1," Crop Science, vol. 6, no. 1, pp. 36-40, 1966.

[30] A. Pour-Aboughadareh, M. Yousefian, H. Moradkhani, P. Poczai, and K. H. M. Siddique, "STABILITYSOFT: a new online program to calculate parametric and non-parametric stability statistics for crop traits," Applications in Plant Sciences, vol. 7, no. 1, Article ID e01211, 2019.

[31] H. G. Gauch Jr. and R. W. Zobel, "AMMI analysis of yield trial," in Genotype-by-environment Interaction, M. S. Kang 
and H. G. Gauch Jr., Eds., CRC Press, Boca Raton, FL, USA, 1996.

[32] H. G. Gauch Jr., P. Annicchiarico, and P. Annicchiarico, "Statistical analysis of yield trials by AMMI and GGE: further considerations," Crop Science, vol. 48, no. 3, pp. 866-889, 2008.

[33] W. Yan, M. S. Kang, B. Ma, S. Woods, and P. L. Cornelius, "GGE biplot vs. AMMI analysis of genotype-by-environment data," Crop Science, vol. 47, no. 2, pp. 643-653, 2007.

[34] H. G. Gauch, "Statistical analysis of yield trials by AMMI and GGE,” Crop Science, vol. 46, no. 4, pp. 1488-1500, 2006.

[35] International Rice Research Institute, Plant Breeding Tools. User's Manual. Biometrics and Breeding Informatics. Plant Breeding, Genetics and Biotechnology Division, International Rice Research Institute, Los Baños, Philippines, 2014.

[36] International Rice Research Institute, Statistics for Agriculture Research. User's Manual. Biometrics and Breeding Informatics. Plant Breeding, Genetics and Biotechnology Division, International Rice Research Institute, Los Baños, Philippines, 2014.

[37] E. Durand, S. Bouchet, P. Bertin et al., "Flowering time in maize: linkage and epistasis at a major effect locus," Genetics, vol. 190, no. 4, pp. 1547-1562, 2012.

[38] J. Steinhoff, W. Liu, J. C. Reif, G. D. Porta, N. Ranc, and T. Würschum, "Detection of QTL for flowering time in multiple families of elite maize," Theoretical and Applied Genetics, vol. 125, no. 7, pp. 1539-1551, 2012.

[39] J. Xu, Y. Liu, J. Liu et al., "The genetic architecture of flowering time and photoperiod sensitivity in maize as revealed by QTL review and meta analysis," Journal of Integrative Plant Biology, vol. 54, no. 6, pp. 358-373, 2012.

[40] D. Ruswandi, E. P. Anggia, E. Suryadi, S. Ruswandi, and N. Rostini, "Seleksi hibrida jagung DR unpad berdasarkan stabilitas dan adaptabilitas hasil di delapan lokasi di Indonesia," Zuriat, vol. 19, no. 1, pp. 71-85, 2008.

[41] J. Ahmadi, B. Vaezi, A. Shaabani, K. Khademi, and S. F. Ourang, "Non- parametric measures for yield stability in grass pea (Lathyrus sativus L.) advanced lines in semi warm regions," Journal of Agricultural Science and Technology, vol. 17, pp. 1825-1838, 2015.

[42] K. Shahzad, T. Qi, L. Guo, H. Tang, and X. Zhang, "Adaptability and stability comparisons of inbred and hybrid cotton in yield and fiber quality traits," Agronomy, vol. 95, no. 16, pp. 1-16, 2019.

[43] V. G. P. Chimonyo, C. S. Mutengwa, and C. Chiduza, "Genotype $\mathrm{x}$ environment interaction and yield stability of stresstolerant open-pollinated maize varieties in the Eastern Cape province, south Africa," South African journal of Plant and Soil, vol. 31, no. 2, pp. 61-68, 2014. 